\title{
Lipid biomarkers preserved in hydrate-associated authigenic carbonate rocks of the Gulf of Mexico
}

\author{
Richard D. Pancost ${ }^{\mathrm{a}, *}$, Chuanlun L. Zhang ${ }^{\mathrm{b}}$, Joe Tavacoli ${ }^{\text {a }}$, Helen M. Talbot ${ }^{\mathrm{c}}$, \\ Paul Farrimond ${ }^{\mathrm{c}}$, Stefan Schouten ${ }^{\mathrm{d}}$, Jaap S. Sinninghe Damsté ${ }^{\mathrm{d}}$, Roger Sassen ${ }^{\mathrm{e}}$ \\ ${ }^{a}$ Organic Geochemistry Unit, The Bristol Biogeochemistry Research Centre, School of Chemistry, University of Bristol, \\ Cantock's Close, Bristol BS8 1TS, UK \\ ${ }^{\mathrm{b}}$ Savannah River Ecology Laboratory, University of Georgia, Drawer E, Aiken, SC 29802, USA \\ ${ }^{\mathrm{c}}$ Newcastle Research Group (NRG), School of Civil Engineering and Geosciences, Drummond Building, \\ University of Newcastle, Newcastle upon Tyne NE1 7RU, UK \\ ${ }^{\mathrm{d} D e p a r t m e n t ~ o f ~ M a r i n e ~ B i o g e o c h e m i s t r y ~ a n d ~ T o x i c o l o g y, ~ R o y a l ~ N e t h e r l a n d s ~ I n s t i t u t e ~ f o r ~ S e a ~ R e s e a r c h ~(N I O Z), ~ P O ~ B o x ~ 59, ~}$ \\ 1790 AB Den Burg, The Netherlands \\ ${ }^{\mathrm{e}}$ Geochemical and Environmental Research Group (GERG), Texas A and M University, College Station, Texas 77845, USA
}

Received 10 March 2004; received in revised form 28 July 2004; accepted 11 April 2005

\begin{abstract}
Anaerobic oxidation of methane (AOM) is common in ocean-margin sediments, where it is mediated by consortia of Archaea and Bacteria and can result in the formation of authigenic carbonate, including extensive carbonate crusts. Previous work indicates that AOM is associated with Gulf of Mexico hydrocarbon seeps and is mediated by similar organisms as identified in other settings; however, biological investigations have not been done on the associated ${ }^{13} \mathrm{C}$-depleted carbonates. Here, we show that ${ }^{13} \mathrm{C}$-depleted archaeal and bacterial biomarkers are abundant in Gulf of Mexico authigenic carbonate rocks, revealing that AOM-mediating organisms are closely associated with carbonate authigenesis. Moreover, the rocks share general characteristics of the background (soft) sedimentary archaeal and bacterial community inferred from biomarker analysis, suggesting that the organisms associated with carbonate authigenesis are the same as those that live elsewhere in the hydrocarbon seep environment. This provides further evidence that AOM by Archaea and sulfate-reducing bacteria can result in the sequestration of significant quantities of methane-derived carbon in carbonate rocks.
\end{abstract}

(C) 2005 Elsevier B.V. All rights reserved.

Keywords: Anaerobic oxidation of methane; Archaea; Bacteria; Gas hydrates; Diether lipids; Hopanoids; Irregular isoprenoids; Authigenic carbonates

\section{Introduction}

* Corresponding author. Tel.: +44 1179289178.

E-mail address: r.d.pancost@bristol.ac.uk (R.D. Pancost).
Gas hydrates are widespread along continental margins of the world's oceans (Henriet and Mienert, 
1998; Kastner, 2001; Kvenvolden and Lorenson, 2001), including the Gulf of Mexico (Brooks et al., 1986; Roberts and Carney, 1997; Sassen et al., 1998), and are thought to represent approximately 0.25 to $1 \times 10^{19} \mathrm{~g}$ of sequestered, but potentially transient, carbon (Kvenvolden and Lorenson, 2001; Milkov et al., 2003). The role of gas hydrates in the global carbon reservoir is of particular importance because they could represent an untapped energy source but are also potential agents of rapid climate change (Dickens et al., 1995; Kennett et al., 2000; Dickens, 2001). Currently, anaerobic oxidation of methane (AOM) consumes about $90 \%$ of the methane produced in anoxic marine sediments and plays an important role in controlling methane release into the atmosphere (Reeburgh, 1996). Gas hydrates are abundant in the Gulf of Mexico, perhaps representing $\sim 10-14$ trillion cubic meters of mainly methane but also $\mathrm{C}_{2}-\mathrm{C}_{5}$ hydrocarbon gases (Sassen et al., 2001; Milkov and Sassen, 2001); as these hydrates degrade releasing methane, AOM occurs in Gulf of Mexico sediments (Zhang et al., 2002, 2003) and plays an important role in carbon cycling and the development of biological communities (Sassen et al., 1993; Aharon and $\mathrm{Fu}, 2000$ ).

As a consequence of AOM, bicarbonate concentrations are very high in pore waters and bottom waters associated with methane seeps, leading to the extensive precipitation of authigenic carbonate in sediment pore spaces and on the seafloor (e.g., Peckmann et al., 1999; Thiel et al., 1999; Greinert et al., 2002; Aloisi et al., 2002). In the Gulf of Mexico, authigenic carbonate rock occurs as extensive pavements, crusts, nodules, and cements. These carbonates increase the seafloor stability (Roberts and Aharon, 1994) and provide favorable surfaces for the development of invertebrate communities in the deep ocean (MacDonald et al., 1989; Nelson and Fisher, 1995; Sassen et al., 1998). Moreover, they are a critical component of carbon cycling at cold seeps as they represent the long-term sequestration of methanederived carbon.

Until recently, the role of microorganisms in AOM was unclear. However, recent work, combining phylogenetic analyses, lipid biomarker quantification and stable isotopic analysis, indicates that consortia of sulfate-reducing bacteria and Archaea work in syntrophy to mediate the anaerobic oxidation of methane in methane-rich sediments (Boetius et al., 2000; Pancost et al., 2000; Orphan et al., 2001a). We have extended these analyses to Gulf of Mexico sediments; there, lipid biomarker abundances and carbon isotopic compositions (Zhang et al., 2002, 2003), as well as phylogenetic analyses (Lanoil et al., 2001; Mills et al., 2003), indicate that AOM is mediated by similar archaeal-bacterial consortia as has been reported elsewhere. However, there has been no comparable work on the authigenic carbonate rocks in the Gulf of Mexico; in fact, there have been relatively few biomarker-based investigations of modern cold seep carbonate crusts and other authigenic carbonates (Elvert et al., 2000, 2001; Thiel et al., 2001; Aloisi et al., 2002; Michaelis et al., 2002; Stadnitskaia et al., 2003). Here, we have determined biomarker distributions and carbon isotopic compositions in five authigenic carbonate rocks associated with Green Canyon, Gulf of Mexico, hydrocarbon seeps. These distributions are compared to nearby sediments and biomarker distributions in Black Sea (Thiel et al., 2001) and Mediterranean mud volcano (Aloisi et al., 2002) carbonates.

\section{Material and methods}

Samples were collected from the Green Canyon (GC) region of the Gulf of Mexico (Fig. 1) using the Johnson Sea-Link research submersible. The mechanical arm of the submersible was used to sample a slab of authigenic carbonate rock outcropping on the sea floor (at site GC185) and to excavate small carbonate nodules from $<0.25 \mathrm{~m}$ depth in sediment (all other sites; Fig. 1). Details of sites are provided in Table 1. Gas hydrate occurs at sites GC185, 232, and 234, but is absent near the GC233 brine pool site because dense brines retard gas hydrate crystallization. All sites are associated with hydrocarbondriven chemosynthetic communities characterized by tube worms that utilize $\mathrm{H}_{2} \mathrm{~S}$ and mussels with bacterial symbionts within their gill tissues that utilize methane.

\subsection{Extraction and fractionation}

Carbonate rocks were frozen at $-20{ }^{\circ} \mathrm{C}$ immediately upon recovery at the sea surface and kept frozen until 


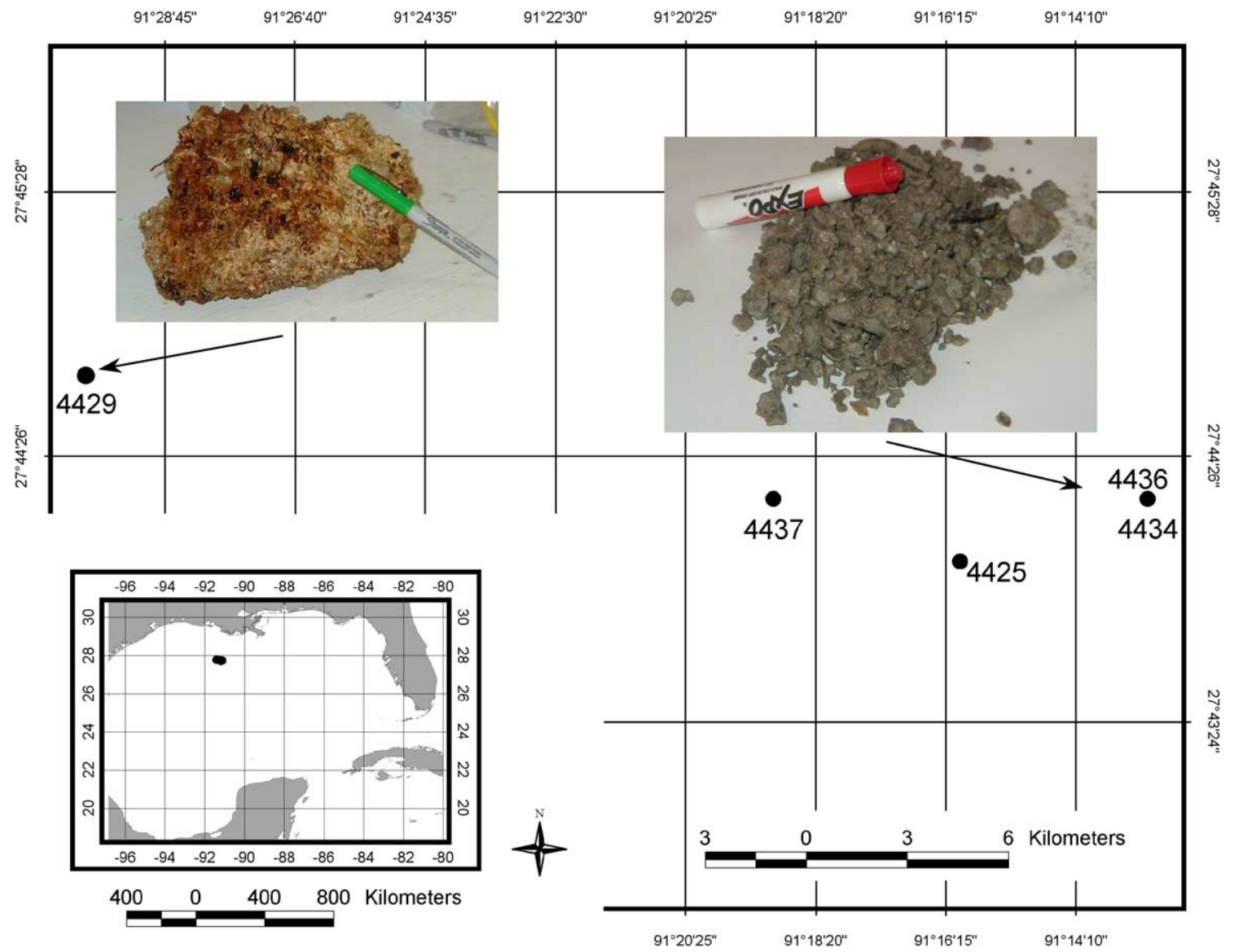

Fig. 1. Location of Green Canyon region in the Gulf of Mexico, where carbonate rocks and nodules were collected from sites 185, 232, 233 and 234 (during submersible dives 4434 and 4436) and photos of a carbonate crust from Site 185 (note the oil stain on the crust's surface) and carbonate nodules from Site 234 (Dive 4436).

analysis. Rocks were broken into small (ca. $1 \mathrm{~cm}^{3}$ ) pieces and pre-cleaned three times each via sonication in a sequence of solvent mixtures with increasing methanol/dichloromethane $(\mathrm{DCM})$ ratios $(0: 1 \mathrm{v} / \mathrm{v}$, three times, $1: 1 \mathrm{v} / \mathrm{v}$, three times, and $1: 0 \mathrm{v} / \mathrm{v}$, three times). The samples were then ground to a fine powder

Table 1

Sample description of carbonate rocks and nodules from Green Canyon, Gulf of Mexico

\begin{tabular}{|c|c|c|c|c|c|}
\hline Site & Dive & $\begin{array}{l}\text { Water } \\
\text { depth }(m)\end{array}$ & Latitude & Longitude & Sample description \\
\hline GC 185 & D4429 & 543 & $27^{\circ} 47.0^{\prime} \mathrm{N}$ & $91^{\circ} 30.4^{\prime} \mathrm{W}$ & $\begin{array}{l}\text { Carbonate nodules with oil stain; } \\
\text { but no tubeworms }\end{array}$ \\
\hline GC 232 & D4437 & 569 & $27^{\circ} 44.5^{\prime} \mathrm{N}$ & $91^{\circ} 19.1^{\prime} \mathrm{W}$ & $\begin{array}{l}\text { Carbonate nodules from tubeworm roots, } \\
\text { dark gray, no oil stain }\end{array}$ \\
\hline GC 233 & D4425 & 650 & $27^{\circ} 43.3^{\prime} \mathrm{N}$ & $91^{\circ} 16.8^{\prime} \mathrm{W}$ & $\begin{array}{l}\text { Carbonate nodules and from tubeworm roots, } \\
\text { gray, no oil stain }\end{array}$ \\
\hline GC 234 & D4434 & 540 & $27^{\circ} 44.7^{\prime} \mathrm{N}$ & $91^{\circ} 13.3^{\prime} \mathrm{W}$ & Carbonate nodules, gray \\
\hline GC 234 & D4436 & 540 & $27^{\circ} 44.7^{\prime} \mathrm{N}$ & $91^{\circ} 13.3^{\prime} \mathrm{W}$ & Carbonate nodules and tubeworms, gray \\
\hline
\end{tabular}


and $100 \mathrm{~g}$ of the powdered rock was extracted via Soxhlet apparatus for $24 \mathrm{~h}$ in a $2: 1$ azeotrope of DCM:Methanol. Elemental sulfur was removed from the total extracts by reaction with ca. $5 \mathrm{~g}$ of activated copper for $24 \mathrm{~h}$.

Total lipid extracts were separated into different compound class fractions using a combination of bond-elut (Kim and Norman, 1990) and flash column chromatography. Varian and Phenomenex aminopropyl $\left(\mathrm{NH}_{2}\right)$ Bond Elut solid phase columns $(100 \mathrm{mg}$ sorbent bed) were used to separate the total lipid extract into neutral, acid and polar/phospholipid fractions. The columns were conditioned with methanol and 2:1 DCM: iso-propanol, immediately prior to use, and the sample (ca. 2-5 mg TLE) was loaded onto the column and eluted with: $12 \mathrm{ml}$ of $2: 1$ DCM: iso-propanol (neutral fraction); $12 \mathrm{ml}$ of $2 \%$ $(\mathrm{v} / \mathrm{v})$ acetic acid in diethyl ether (acid fraction); and 12 $\mathrm{ml}$ of methanol (polar/phospholipid fraction). Each of the fractions was then rotary evaporated to approximately $1 \mathrm{ml}$ and passed through $0.40 \mathrm{~g}$ of $\mathrm{MgSO}_{4}$ (to remove any water from the sample) in $n$-hexane. The neutral fraction was further separated into apolar and polar fractions on an alumina column (40 g activated alumina). The apolar fraction was collected using hexane/dichloromethane $(9: 1, \mathrm{v} / \mathrm{v})$ as the eluent, and the polar fraction was collected using methanol as the eluent.

\subsection{Gas chromatography and gas chromatograpy- mass spectrometry}

Quantification of lipids was performed using a combination of gas chromatography (GC) and GCmass spectrometry (MS). GC was conducted on a Carlo Erba HRGC 5300 Mega Series instrument, equipped with a flame ionization detector and a $\mathrm{CP}$ Sil-5CB (dimethylpolysiloxane, $0.12 \mu \mathrm{m} \mathrm{df}$ ) fused silica capillary column $(25 \mathrm{~m}, 0.32 \mathrm{~mm}$ id $)$. Samples were injected at $70{ }^{\circ} \mathrm{C}$ using an on-column injector and the oven was heated to $130{ }^{\circ} \mathrm{C}$ at 20 ${ }^{\circ} \mathrm{C} / \mathrm{min}$ then at $4{ }^{\circ} \mathrm{C} / \mathrm{min}$ to $300{ }^{\circ} \mathrm{C}$, at which the temperature was held for $20 \mathrm{~min}$. The carrier gas was $\mathrm{H}_{2}$. GC-MS was performed using a Thermoquest Finnigan TRACE GC interfaced to a Thermoquest Finnigan TRACE MS operated with electron ionisation at $70 \mathrm{eV}$ and scanning a $\mathrm{m} / \mathrm{z}$ range of 50 to 800 . GC column and temperature program were the same as that used in GC analyses, but the carrier gas was He.

\subsection{Analysis of hopanoids}

The experimental methods have been fully detailed elsewhere (Innes et al., 1997; Farrimond et al., 2000). Freeze-dried, powdered samples were extracted with chloroform/methanol (180 ml; 2:1 v/v) using a Gerhardt Soxtherm apparatus. After evaporation to dryness an internal standard ( $5 \alpha$-androstanol) was added for quantitation by gas chromatography-mass spectrometry (GC-MS). The total extract was split into aliquots for derivatisation targeted at different specific hopanoid functionalities prior to analysis (see Innes et al., 1997). One aliquot was treated with periodic acid and sodium borohydride to convert the BHPs to more readily analysable terminal alcohols (Rohmer et al., 1984; Innes et al., 1997). These were subsequently acetylated (acetic anhydride/pyridine, $4 \mathrm{ml} ; 1: 1 \mathrm{v} / \mathrm{v}$; $50{ }^{\circ} \mathrm{C}$ for $1 \mathrm{~h}$ ), as was a second aliquot of the total extract for the detection of hopanols and the more GC-amenable BHPs.

Hopanols and BHPs were analysed by gas chromatography-mass spectrometry (GC-MS) using a Hewlett-Packard 5890 II GC system (split/splitless injector; $350{ }^{\circ} \mathrm{C}$ ) linked to a Hewlett-Packard 5972 mass-selective detector (electron energy $70 \mathrm{eV}$; filament current $220 \mu \mathrm{A}$; source temperature $270{ }^{\circ} \mathrm{C}$; multiplier voltage $2000 \mathrm{~V}$; interface temperature 350 ${ }^{\circ}$ C). A 15 m DB5-HT fused silica column $(0.25 \mathrm{~mm}$ i.d.; $0.1 \mu \mathrm{m}$ film thickness) was used with helium as the carrier gas. The oven temperature was programmed from 50 to $200{ }^{\circ} \mathrm{C}$ at $15{ }^{\circ} \mathrm{C} / \mathrm{min}$ (held for $1 \mathrm{~min}$ ), from 200 to $250{ }^{\circ} \mathrm{C}$ at $10{ }^{\circ} \mathrm{C} / \mathrm{min}$ (held for $1 \mathrm{~min}$ ) and from 250 to $350{ }^{\circ} \mathrm{C}$ at $5{ }^{\circ} \mathrm{C} / \mathrm{min}$ (held for $8 \mathrm{~min}$ ). Hopanoids were identified from full scan ( $\mathrm{m} / \mathrm{z}$ 50-700) analysis of selected samples, by comparison with authentic standards and published spectra and by relative retention times. Components of interest were quantified using selected ion monitoring (SIM) data utilising peak areas in the $\mathrm{m} / z 191$ mass chromatograms compared to the $\mathrm{m} / \mathrm{z} 243$ peak area response of the androstanol internal standard assuming a relative response factor of $1: 1$.

The high performance liquid chromatography atmospheric pressure chemical ionisation multistage mass spectrometry (HPLC-APCI-MS ${ }^{\mathrm{n}}$ ) methodology 
has been reported in full elsewhere (Talbot et al., 2003a,b). Reversed-phase HPLC of acetylated extracts (injected in $\mathrm{MeOH}$ :propan-2-ol, 60:40 v/v) was accomplished using a Surveyor HPLC system (ThermoFinnigan, Hemel Hempstead, UK) fitted with a Genesis (Jones Chromatography, Hengoed, UK) $\mathrm{C}_{18} 4 \mu \mathrm{m}$ HPLC column $(150 \times 4.6 \mathrm{~mm}$ I.D. $)$ and a $4 \mu \mathrm{m}$ precolumn $(10 \times 4.6 \mathrm{~mm}$ I.D. $)$ of the same material. Separation was achieved at ambient temper-

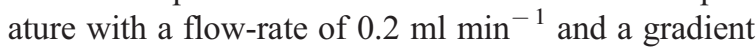
profile of: $90 \% \mathrm{~A}$ and $10 \% \mathrm{~B}(0-3 \mathrm{~min}) ; 59 \% \mathrm{~A}, 1 \%$ $\mathrm{B}$ and $40 \% \mathrm{C}$ (at $25 \mathrm{~min}$ ) then isocratic to $60 \mathrm{~min}$ (where $\mathrm{A}=\mathrm{MeOH}, \mathrm{B}=$ water and $\mathrm{C}=$ propan-2-ol; all HPLC grade, purchased from Fisher [Loughborough, UK]). LC/MS ${ }^{\mathrm{n}}$ was performed using a Finnigan LCQ ion trap mass spectrometer equipped with an APCI source operated in positive ion mode. LC/MS settings were as follows: capillary temperature $155^{\circ} \mathrm{C}$, APCI vaporiser temperature $400{ }^{\circ} \mathrm{C}$, corona discharge current $8 \mu \mathrm{A}$, sheath gas flow 40 and auxiliary gas 10 (arbitrary units). Detection was achieved at an isolation width of 3.0 and fragmentation with normalised collisional dissociation energy of $35 \%$.

\subsection{Analysis of tetraether lipids}

Analyses were performed on total lipid extracts using an HP (Palo-Alto, CA, USA) 1100 series LCMS equipped with an auto-injector and Chemstation chromatography manager software. Separation was achieved on an Prevail Cyano column $(2.1 \times 150$ $\mathrm{mm}, 3 \mu \mathrm{m}$; Alltech, Deerfield, IL, USA), maintained at $30{ }^{\circ} \mathrm{C}$. Injection volumes varied from 1 to $5 \mu \mathrm{l}$. Tetraethers were eluted isocratically with $99 \% \mathrm{~A}$ and

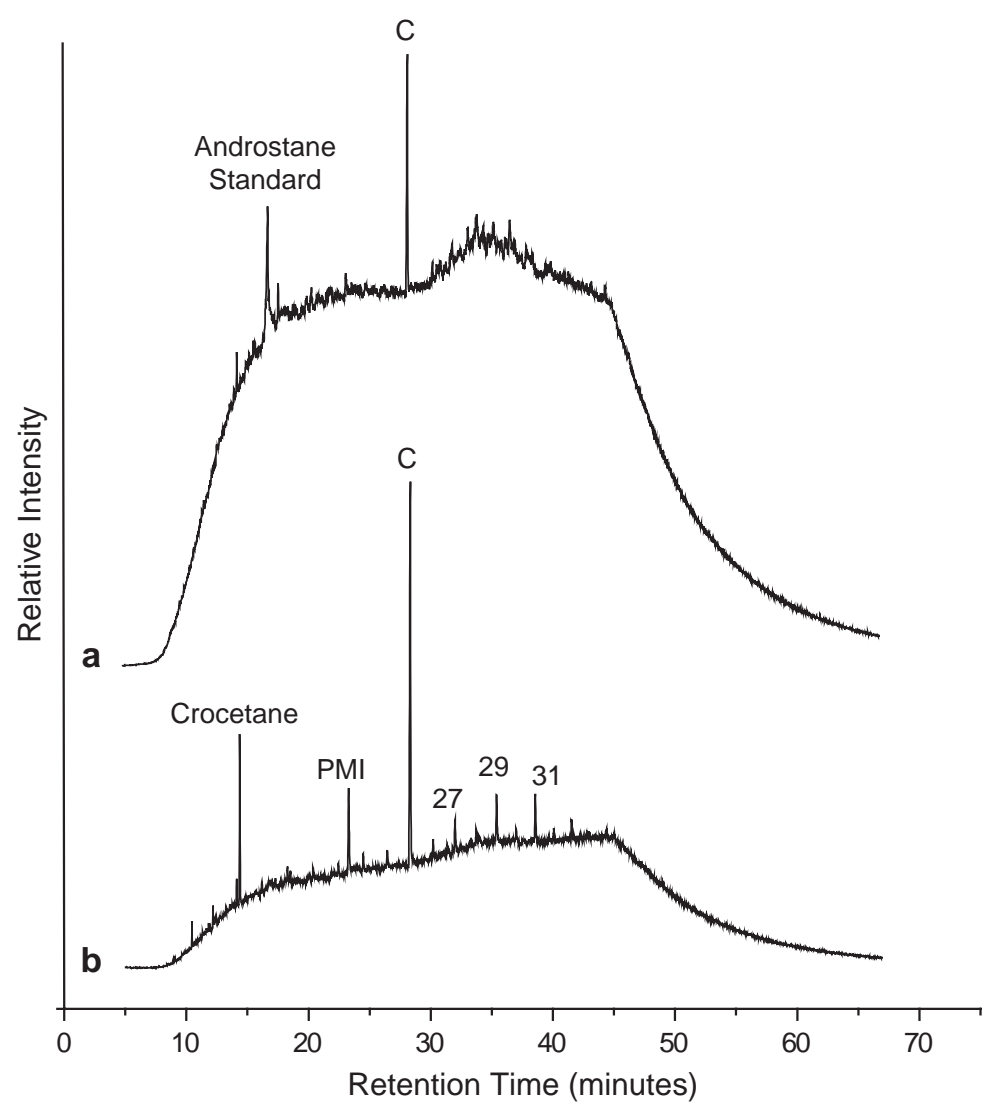

Fig. 2. Partial total ion current chromatogram (a) and $m / z 57$ mass chromatogram (b) of a typical Gulf of Mexico, Green Canyon, carbonate rock (Site GC233) apolar hydrocarbon fraction. Numbers denote $n$-alkanes while C denotes a pthalate contaminant. 
$1 \% \mathrm{~B}$ for $5 \mathrm{~min}$, followed by a linear gradient to $1.8 \%$ $\mathrm{B}$ in $45 \mathrm{~min}$, where $\mathrm{A}=$ hexane and $\mathrm{B}=$ propanol. Flow rate was $0.2 \mathrm{ml} / \mathrm{min}$. After each analysis the column was cleaned by back-flushing hexane/propanol $(90: 10, \mathrm{v} / \mathrm{v})$ at $0.2 \mathrm{ml} / \mathrm{min}$ for $10 \mathrm{~min}$. Detection was achieved using atmospheric pressure positive ion chemical ionization mass spectrometry (APCIMS) of the eluent. Conditions for APCI-MS were as follows: nebulizer pressure 60 psi, vaporizer temper- ature $400{ }^{\circ} \mathrm{C}$, drying gas $\left(\mathrm{N}_{2}\right)$ flow $6 \mathrm{l} / \mathrm{min}$ and temperature $200{ }^{\circ} \mathrm{C}$, capillary voltage $-3 \mathrm{kV}$, corona $5 \mu \mathrm{A}(\sim 3.2 \mathrm{kV})$. Positive ion spectra were generated by scanning $\mathrm{m} / \mathrm{z}$ 950-1450 in $1.9 \mathrm{~s}$.

\subsection{Compound-specific carbon isotope analysis}

GC-C-IRMS was conducted using a Hewlett Packard gas chromatograph interfaced via a Thermoquest

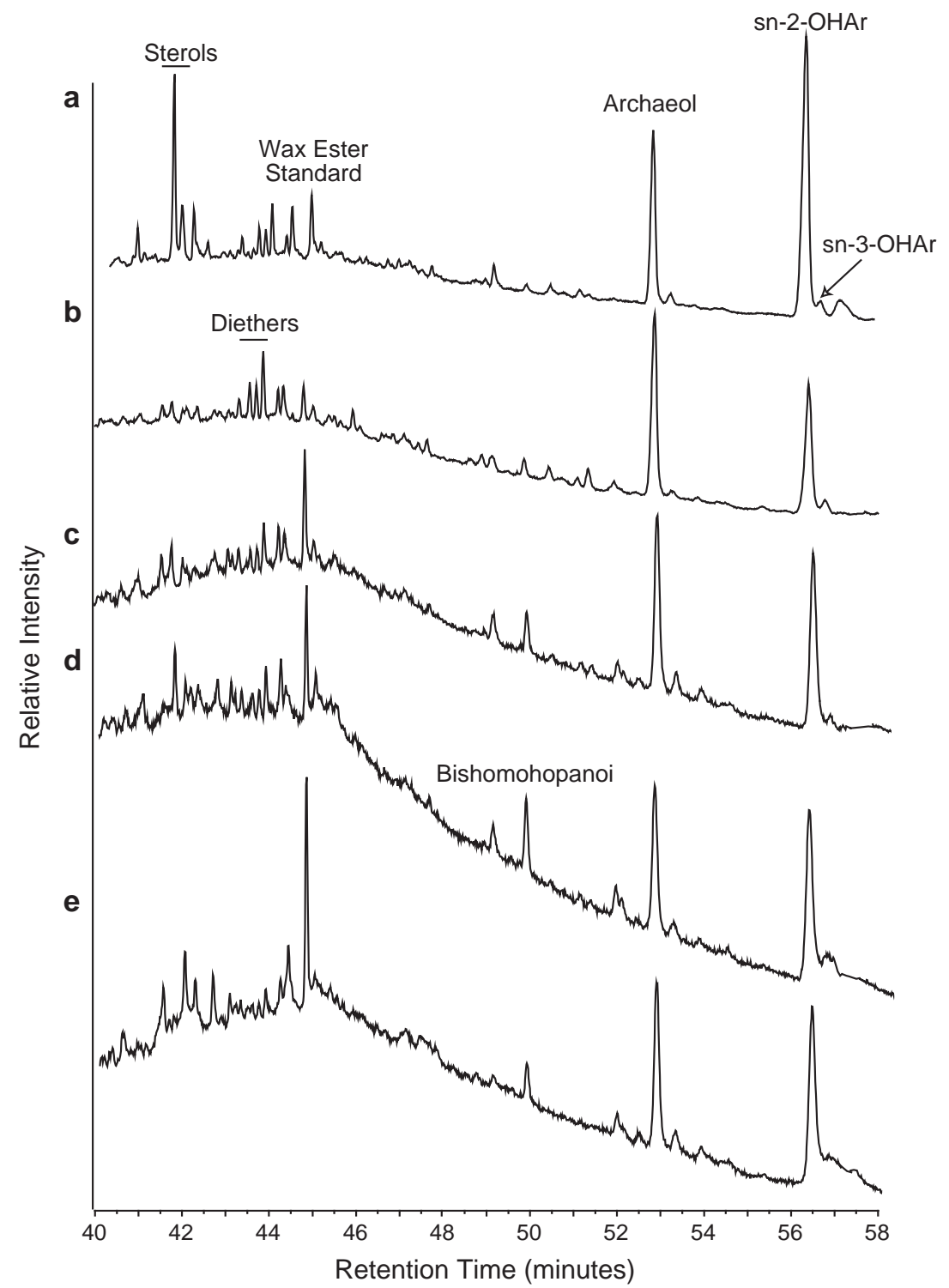

Fig. 3. Partial total ion current chromatograms of Gulf of Mexico, Green Canyon, carbonate rock neutral polar fractions (analysed as TMS ethers): a, Site GC234 (Dive 4436); b, Site GC232; c, Site GC233; d, Site GC234 (Dive 4434); e, Site GC185. 
Finnigan GC III combustion interface to a Thermoquest Finnigan Delta $\mathrm{S}$ mass spectrometer. The GC was equipped and operated as for the GC-MS analyses. Measurements were performed in duplicate and values are reported in standard delta notation relative to V-PDB. Errors were typically less than $1.5 \%$ o based on duplicate measurements and internal or co-injected standards. These errors are somewhat larger than those normally observed (ca. $0.3 \%$ ) and reflect the relatively high baseline (due to the presence of biodegraded petroleum) and/or co-elution with small background peaks.

\section{Results}

\subsection{Lipid Biomarkers of authigenic carbonate rocks}

The dominant characteristic of both the hydrocarbon (Fig. 2) and neutral polar gas chromatograms is the large unresolved complex mixture (UCM), presumably comprising degraded petroleum hydrocarbons (Sassen et al., 1994a; Zhang et al., 2003). Because we pre-extracted the carbonates prior to grinding them, these hydrocarbons are likely incorporated into the carbonate matrix, in addition to being stained onto the surface of the carbonate rocks, and was present prior to carbonate precipitation.

Other than the UCM, the dominant components of the carbonate rocks' hydrocarbon and neutral polar fractions (Fig. 3) are archaeal biomarkers (see Appen-

Table 2

Abundances of archaeal and non-petroleum related bacterial biomarkers and biodegraded petroleum ( $\mu \mathrm{g} \mathrm{g}^{-1}$ rock) in Gulf of Mexico, Green Canyon, carbonate rocks

\begin{tabular}{llllll}
\hline Compound & \multirow{2}{*}{ GC185 } & GC232 & GC234- & GC233 & GC234- \\
& & & D4434 & D4436 \\
\hline Archaeol & 2.8 & 7.7 & 4.1 & 1.6 & 3.9 \\
sn-2-hydroxyarchaeol & 5.0 & 10.8 & 12.3 & 4.2 & 11.1 \\
sn-3-hydroxyarchaeol & 0.1 & 0.8 & 0.5 & 0.3 & 0.3 \\
Crocetane & 1.8 & n.d. $^{\text {a }}$ & n.d. & 0.5 & 0.8 \\
PMI & 1.4 & n.d. & n.d. & 0.5 & 0.8 \\
di-C ${ }_{15}$ glycerol & 4.5 & 6.0 & 1.5 & 0.8 & 1.7 \\
$\quad$ diether & & & & & \\
UCM & 8800 & n.d. & 1200 & 7300 & 1200
\end{tabular}

${ }^{\mathrm{a}}$ Not determined, due to low abundance of standard relative to complex hydrocarbon mixture.

${ }^{b}$ Abundance shown is for sum of all di- $\mathrm{C}_{15}$ glycerol diethers.

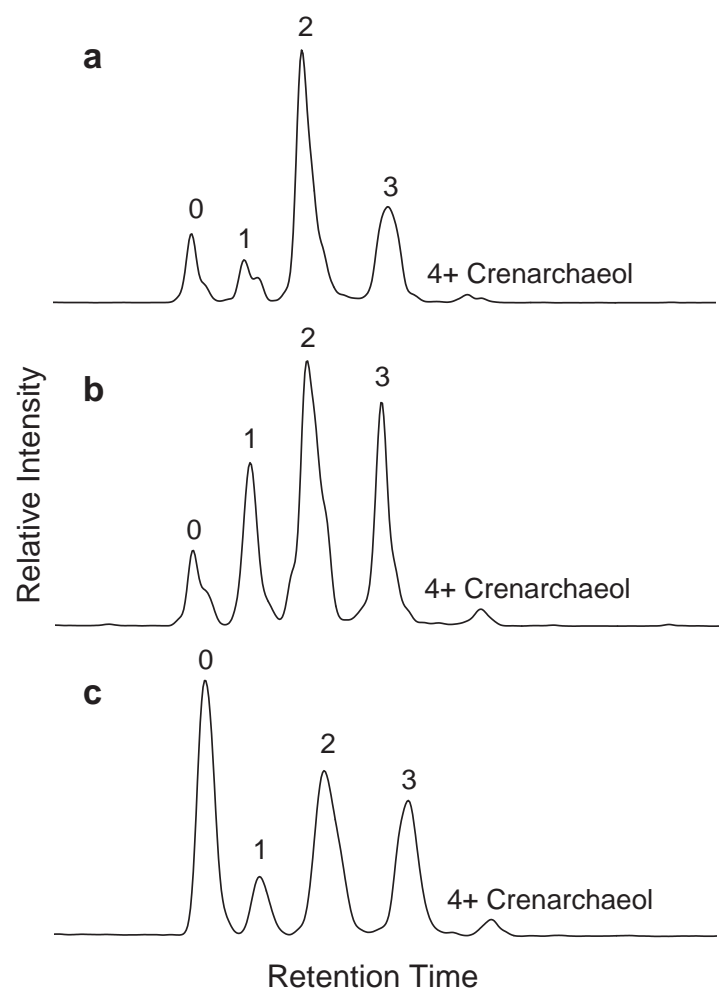

Fig. 4. Partial base peak mass chromatograms from LC-MS analyses of Gulf of Mexico, Green Canyon, carbonate rock neutral polar fractions (showing glycerol dialkyl glycerol tetraethers): a, Site GC233; b, Site GC234 (Dive 4436); c, Site GC185. Numbers denote the total number of cyclopentanyl moieties in the two biphytane chains of the GDGTs.

dix A). All five examined carbonates contain abundant archaeol (I), sn-2-hydroxyarchaeol (II), crocetane (IV) and PMI (pentamethylicosane; V), all derived exclusively from Archaea (De Rosa and Gambacorta, 1988). Archaeol (2-8 $\mu \mathrm{g} \mathrm{g}^{-1}$ ground rock) and $s n-2-$ hydroxyarchaeol (2-12 $\mu \mathrm{g} \mathrm{g}^{-1}$ ground rock) are the most abundant of the quantified archaeal biomarkers; of the two, $s n$-2-hydroxyarchaeol is generally more abundant (Table 2), with concentrations being one to three times greater than archaeol in a given carbonate. Sn-3-hydroxyarchaeol (III), which has been reported in other cold seep sediments (Pancost et al., 2001a) but absent from several others (e.g., Hinrichs et al., 2000), is present but in much lower concentrations ( 0.1 to $0.5 \mu \mathrm{g} \mathrm{g}^{-1}$ ground rock). While the hydrocarbon fractions (Fig. 2) are dominated by degraded petroleum hydrocarbons, including low abundances 
of $n$-alkanes and hopanes, PMI and crocetane are present $\left(0.5\right.$ to 1.4 and 0.5 to $1.8 \mu \mathrm{g} \mathrm{g}^{-1}$ ground rock, respectively), albeit in lower abundances than archaeal diethers.

Intact isoprenoid glycerol dialkyl glycerol tetraethers (GDGTs; VI), although not quantified, are also present in all five carbonate rocks as indicated by the major peaks in the LC-MS chromatograms (Fig. 4). All GDGTs are comprised of two ether-bound biphytanyl chains with varying numbers of cyclopentanyl moieties: an acyclic-acyclic GDGT (0); a monocyclic-acyclic GDGT (1); a peak that appears to be a mixture of acyclic-bicyclic and monocyclic-monocyclic (2) GDGTs; a bicyclic-monocyclic GDGT (3); and crenarchaeol, a GDGT comprised of the common bicyclic biphytanyl moiety and a tricyclic biphytanyl moiety in which one cyclic group is a cyclohexyl rather than cyclopentanyl moiety (Schouten et al., 2000; Sinninghe Damsté et al., 2002; see Pancost et al., 2001a for a detailed interpretation of cold seep
GDGT distributions). GDGT-0 and crenarchaeol have previously been observed in a Gulf of Mexico control sediment (pelagic sediment not associated with cold seeps; Zhang et al., 2003) and likely derive from pelagic crenarchaea (Schouten et al., 2000; Sinninghe Damsté et al., 2002); in the control sediment, acyclic caldarchaeol and crenarchaeol have similar abundances, and acyclic GDGT-0 abundances in Fig. 4 surpassing those of crenarchaeol likely derive from cold seep Archaea (cf. Pancost et al., 2001a; Wakeham et al., 2003).

Non-isoprenoidal dialkyl glycerol diethers, inferred to derive from bacterial rather than archaeal sources (Pancost et al., 2001b), are also present in the carbonate rocks. We previously reported (Zhang et al., 2003) at least six such compounds in Gulf of Mexico sediments, where they appeared to comprise two pseudohomologous series similar to those previously described by Pancost et al. (2001b). Indeed, in the carbonate nodules collected from site 232, diethers

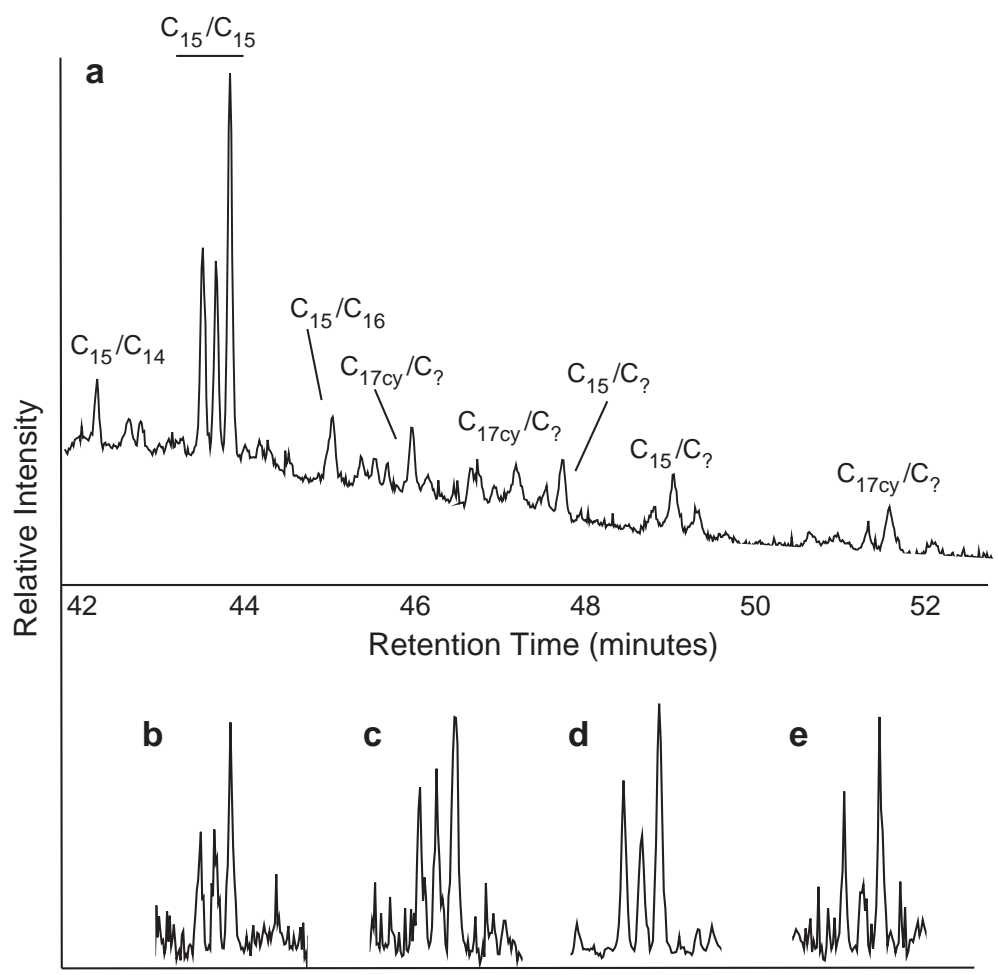

Fig. 5. Partial $\mathrm{m} / \mathrm{z} 130$ mass chromatogram showing the distribution of non-isoprenoidal diethers (analysed as TMS ethers) in Gulf of Mexico, Green Canyon, carbonate rock neutral polar fractions: a, Site GC232; b, Site GC233; c, Site GC234 (Dive 4434); d, Site GC234 (Dive 4436); e, Site GC185. Retention times for partial gas chromatograms in (b-e) extend from 43 to 44.5 min. 
containing either a $\mathrm{C}_{15}$ (inferred to be anteisobranched) or a $\mathrm{C}_{17}$ (bearing a cyclopropyl moiety) alkyl component are present (Fig. 5). The most abundant non-isoprenoidal diethers are three isomers of the di- $\mathrm{C}_{15}$ glycerol diether; based on their relative retention times, they appear to be, in order of increasing retention time, the iso- $\mathrm{C}_{15} /$ iso $-\mathrm{C}_{15}$, anteiso $-\mathrm{C}_{15} /$ iso$\mathrm{C}_{15}$ and anteiso- $\mathrm{C}_{15}$ /anteiso- $\mathrm{C}_{15}$ isomers (compounds Id, Ie and If of Pancost et al., 2001b and compounds VII, VIII and IX here; Appendix A). In the other carbonate rocks, the three di- $\mathrm{C}_{15}$ glycerol diethers are the most abundant; other diethers are present but their abundances are too low to allow tentative structural assignments.
Hopanoids, mainly bishomohopanol (Fig. 6a) and bishomohopanoic acid, both likely degradation products of bacteriohopanepolyols (BHP; e.g., Farrimond et al., 2000) are present in all five rocks. The hopanoic acids in both cold seep carbonates and sediments occur as both the $17 \beta, 21 \beta(\mathrm{H})$ isomer found in living Bacteria and the more thermally stable $17 \alpha, 21 \beta(\mathrm{H})$ isomer formed during catagenesis (Peters and Moldowan, 1991). Ratios of the $\alpha \beta$ to $\beta \beta$ isomer range from 0.3 to 1.2. Except for sample 185, bishomohopanol occurs only as the $17 \beta, 21 \beta(\mathrm{H})$ isomer and has abundances ranging from 0.04 to $0.5 \mu \mathrm{g} \mathrm{g}^{-1}$ in the carbonate rocks.

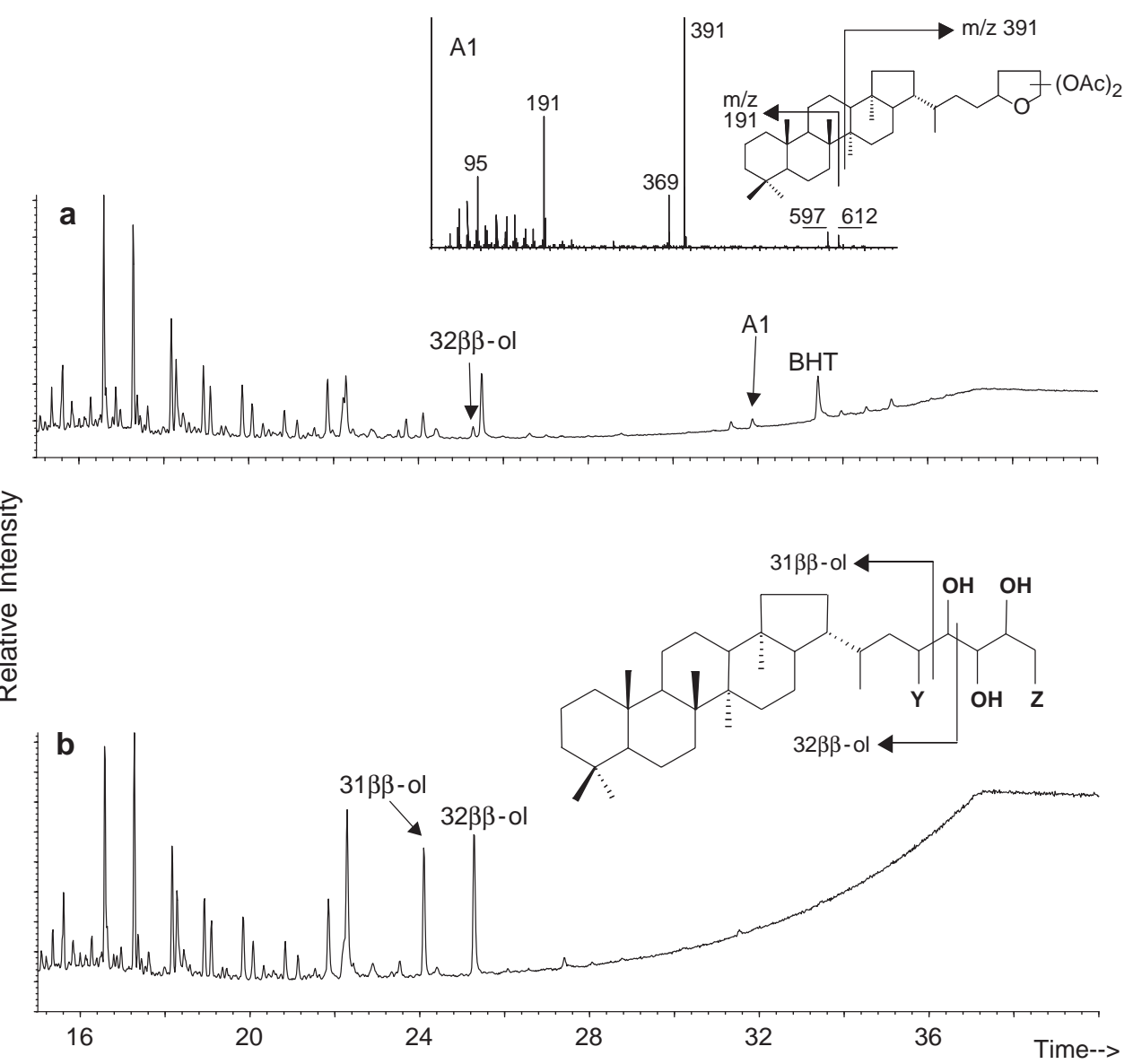

Fig. 6. Partial high temperature gas chromatograms showing (a) acetate derivatives of hopanols and bacteriohopanepolyols in the lipid extract of the Site GC185 carbonate rock (inset shows structure and mass spectrum of 32,35-anhydrobacteriohopanetetrol) and (b) hopanols generated after periodic cleavage of bacteriohopanepolyols in the extract. Inset in (a) shows tentatively identified structure of A1, and inset in (b) shows how cleavage of bacteriohopanetetrol and -pentol results in formation of bishomohopanol and homohopanol, respectively. 
To further examine the distribution of hopanoids, we extracted the ground rocks with chloroform/ methanol (as described in the Material and methods) and quantified the hopanols (as acetate derivatives) using high temperature gas chromatography (Table 3). This extraction technique released homohopanol as well as bishomohopanol; the former is typically present at lower abundances but is more abundant in the carbonate slab from site 185 and the carbonate nodules from site 232. The extracts also contain higher-molecular-weight hopanoids, including 32,35anhydrobacteriohopanetetrol (identification based on comparison to mass spectra published in Costantino et al., 2001) and bacteriohopanetetrol, a widespread biological precursor for hopanols and hopanoic acids found in sediments. Two carbonate rock extracts contain low quantities of bacteriohopanepentol.

Upon periodic cleavage, which breaks the vicinal diol bond, thus releasing $C_{31}$ hopanol from bacteriohopanepentol and $\mathrm{C}_{32}$ hopanol from bacteriohopanetetrol (Fig. 6b), most of the authigenic carbonate rock extracts yielded predominantly bishomohopanol, consistent with a predominance of bacteriohopanetetrol (Fig. 6b, inset). However, periodic cleavage of the extract from the site 185 carbonate slab yielded both $\mathrm{C}_{31}$ and $\mathrm{C}_{32}$ hopanol. LC-MS was used to further examine the high-molecular-weight hopanoids (Fig. 7), confirming the presence of bacteriohopanetetrol and revealing the presence of 35-aminobacteriohopane-32,33,34-triol (aminotriol), both potential sources of the $\mathrm{C}_{32}$ hopanol. LC-MS also revealed the presence of 35-aminobacteriohopane-31,32,33,34-tetrol (aminotetrol), which probably served as the source of the $\mathrm{C}_{31}$ hopanol.

In addition to hopanoids and diethers, other bacterial biomarkers in these samples are both free and phospholipid-bound fatty acids. However, abundances of these compounds were generally low and potentially diagnostic fatty acids (e.g., Hinrichs et al., 2000; Elvert et al., 2003) were not detected.

\subsection{Stable carbon isotopes}

Carbon isotopic compositions were determined for selected biomarkers (Table 4). Others were not determined because of either co-elution of peaks, the presence of the UCM or low abundance of the biomarker. In all carbonates, archaeol and hydroxyarchaeol (isomers integrated as a single peak) $\delta^{13} \mathrm{C}$ values are low, ranging from $-87 \%$ o to $-107 \%$ and $-99 \%$ to $-117 \%$, respectively. These values are depleted in ${ }^{13} \mathrm{C}$ relative to previously reported Gulf of Mexico non-lithified sedimentary archaeal biomarker $\delta^{13} \mathrm{C}$ values: archaeol $\delta^{13} \mathrm{C}$ values range from is $-75 \%$ o to $-98 \%$, while those of $s n$-2-hydroxyarchaeol range from $-82 \%$ o to $-105 \%$ o (Zhang et al., 2003 but also additional data of Pancost and Zhang from GC234). Previous work has shown that non-carbonate sedimentary PMI and crocetane (and unsaturated components)

Table 3

Abundances of bacterial hopanoids ( $\mu \mathrm{g} \mathrm{g}^{-1}$ rock) in Gulf of Mexico, Green Canyon, carbonate rocks

\begin{tabular}{|c|c|c|c|c|c|}
\hline Compound & $\mathrm{GC} 185$ & GC232 & GC234-D4434 & GC233 & GC234-D4436 \\
\hline Bacteriohopanetetrol (BHT) 1 & 1.09 & 0.16 & 0.31 & 0.16 & 0.13 \\
\hline Bacteriohopanetetrol 2 & 0 & 0 & 0.08 & 0.02 & 0.02 \\
\hline 2Me-BHT & 0 & 0 & 0 & 0 & 0 \\
\hline Bacteriohopanepentol & 0 & 0.03 & 0.03 & 0 & 0 \\
\hline A1 & 0.18 & 0.15 & 0.16 & 0.08 & 0.08 \\
\hline $\mathrm{A} 1^{\prime}$ & 0 & 0.05 & 0.00 & 0.08 & 0.06 \\
\hline $17 \beta, 21 \beta(H)$-bishomohopanol & 0.18 & 0.17 & 0.54 & 0.09 & 0.16 \\
\hline $17 \beta, 21 \beta(\mathrm{H})$-bishomohopanol ${ }^{\mathrm{a}}$ & 1.31 & 0.43 & 1.27 & 0.21 & 0.31 \\
\hline $17 \alpha, 21 \beta(\mathrm{H})$-bishomohopanol & 0.27 & 0 & 0 & 0 & 0 \\
\hline $17 \alpha, 21 \beta(\mathrm{H})$-bishomohopanol ${ }^{\mathrm{a}}$ & 0.14 & 0.00 & 0.00 & 0.00 & 0.00 \\
\hline $17 \beta, 21 \beta(\mathrm{H})$-homohopanol & 0.40 & 0.20 & 0.29 & 0.07 & 0.04 \\
\hline $17 \beta, 21 \beta(\mathrm{H})$-homohopanol ${ }^{\mathrm{a}}$ & 1.09 & 0.11 & 0.13 & 0.04 & 0.02 \\
\hline Bishomohopanoic acid $\alpha \beta / \beta \beta$ Ratio & 0.33 & 1.19 & 0.30 & 0.57 & 0.30 \\
\hline
\end{tabular}

\footnotetext{
${ }^{\mathrm{a}}$ Hopanol abundance after periodic cleavage of bacteriohopanepolyols.
} 


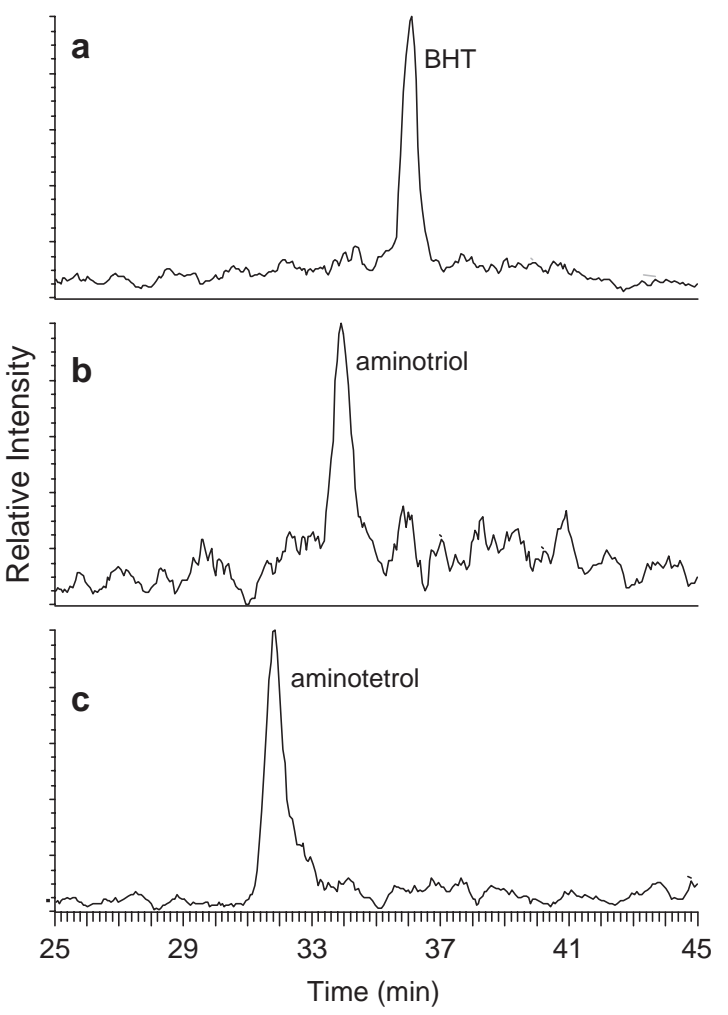

Fig. 7. Partial LC-MS mass chromatograms showing the presence of bacteriohopane-32,33,34,35-tetrol (BHT; $m / z$ 655, a), 35-aminobacteriohopane-32,33,34-triol $(\mathrm{m} / \mathrm{z} 714, \mathrm{~b})$ and 35-aminobacteriohopane-31,32,33,34-tetrol $(\mathrm{m} / \mathrm{z} 772, \mathrm{c})$ in carbonate rock from Site GC185.

are also depleted in ${ }^{13} \mathrm{C}$, but hydrocarbon $\delta^{13} \mathrm{C}$ values could not be determined here due to the large UCM.

Carbon isotopic compositions were determined for the most abundant of the di- $\mathrm{C}_{15}$ glycerol diethers (inferred anteiso/anteiso component) in carbonate nodules from sites 232 and 234 (dive $\mathrm{D} 4434)$, and their $\delta^{13} \mathrm{C}$ values are $-77 \%$ and $-81 \%$, respectively. These values are consistent with our previous work, in which two unidentified sedimentary diethers (diether 1 and diether 2) had $\delta^{13} \mathrm{C}$ values of $-83 \%$ and $-74 \%$. For both the rocks and the sediments, non-isoprenoidal diethers are enriched in ${ }^{13} \mathrm{C}$ relative to co-occurring archaeal biomarkers, consistent with previous lipid (Pancost et al., 2000; Hinrichs et al., 2000; Pancost and Sinninghe Damsté, 2003) and bulk (secondary ion mass spectrometry; Orphan et al., 2001a) carbon isotopic analyses. Bishomohopanol $\delta^{13} \mathrm{C}$ values could not be determined but values were obtained for a previously reported and tentatively identified trinorhopanoid ketone (Pancost and Sinninghe Damsté, 2003); as with previous work, the hopanoid is enriched in ${ }^{13} \mathrm{C}$ relative to other bacterial biomarkers but strongly depleted relative to allochthonous organic matter (Table 4).

\section{Discussion}

\subsection{Archaeal and bacterial biomarkers in Gulf of Mexico carbonates}

Several studies have reported the presence of abundant ${ }^{13} \mathrm{C}$-depleted archaeal lipids in methanerich environments (e.g., Elvert et al., 1999, 2001; Hinrichs et al., 1999, 2000; Thiel et al., 1999, 2001; Pancost et al., 2000; 2001a; Teske et al., 2002; Michaelis et al., 2002; Werne et al., 2002; Stadnitskaia et al., 2003). Archaeol is the most common and ubiquitous archaeal diether and is also prominent in methanogens (Tornabene and Langworthy, 1979; Koga et al., 1998). Hydroxyarchaeol is most commonly found in cultured methanogens, particularly in the Methanosarcinales and Methanococcales, with cultures of the former containing the $s n-2$ isomer (Boone et al., 1993; Koga et al., 1998; Sprott et al., 1993). The saturated and unsaturated PMIs have only been observed in cultures of Methanosarcina mazei and Methanolobus bombayensis but are likely present in other Archaea

Table 4

Carbon isotopic compositions (as \%o values relative to VPDB) of archaeal and bacterial biomarkers ( $\mu \mathrm{g} \mathrm{g}^{-1}$ rock) in Gulf of Mexico, Green Canyon, carbonate rocks

\begin{tabular}{|c|c|c|c|c|c|}
\hline Compound & GC185 & GC232 & $\begin{array}{l}\text { GC234- } \\
\text { D4434 }\end{array}$ & GC233 & $\begin{array}{l}\text { GC234- } \\
\text { D4436 }\end{array}$ \\
\hline Archaeol & -88 & -87 & -95 & -107 & -93 \\
\hline Hydroxyarchaeol & -99 & -99 & -100 & -117 & -100 \\
\hline $\begin{array}{l}\text { di- } \mathrm{C}_{15} \text { glycerol } \\
\text { diether }\end{array}$ & n.d. ${ }^{\mathrm{a}}$ & -79 & -83 & n.d. & n.d. \\
\hline $\begin{array}{l}\text { Trinorhopanoid } \\
\text { ketone }\end{array}$ & n.d. & n.d. & -60 & -54 & -54 \\
\hline
\end{tabular}

${ }^{\text {a }}$ Not determined. 
(Schouten et al., 1997). Crocetane has not been observed in cultures; initially, its irregular isoprenoidal structure and common occurrence with PMI led workers to suggest that it derives from Archaea, possibly methanogens (Elvert et al., 1999; Bian et al., 2001). However, its common occurrence in sediments characterized by AOM - and thus archaeal groups distinct from but closely related to known methanogens (Hinrichs et al., 1999) - suggests that it is derived predominantly or exclusively from methanotrophic archaea.

Similar compounds have all been observed in carbonate crusts associated with cold seeps in other settings. Thiel et al. (2001) identified ${ }^{13} \mathrm{C}$-depleted crocetane and PMI (including unsaturated components) in Black Sea carbonates and a microbial mat; they did not report isoprenoidal diethers such as archaeol or hydroxyarchaeol, but did release by $\mathrm{HI} / \mathrm{LiAlH}_{4}$ treatment ${ }^{13} \mathrm{C}$-depleted phytane, presumably from archaeal diethers, and biphytanes, presumably from GDGTs. Consistent with Black Sea carbonates, Aloisi et al. (2002) and Pancost and Sinninghe Damsté (2003) observed ${ }^{13} \mathrm{C}$-depleted crocetane and PMI (unsaturated and saturated components), archaeol, sn-2-hydroxyarchaeol and GDGTs in Mediterranean mud volcano carbonate crusts.

Previous research on cold seep sediments or authigenic carbonate rocks in which phylogenetic and biomarker data has been collected for a common set of samples (Hinrichs et al., 1999; Orphan et al., 2001b; Aloisi et al., 2002) suggests that archaeal biomarker distributions differ depending on whether the ANME-1 or ANME-2 group is present. High hydroxyarchaeol to archaeol ratios, a strong predominance of the $s n$-2-hyroxyarchaeol isomer and high abundances of ether lipids relative to irregular isoprenoids are observed where the ANME-2 cluster is predominant (e.g., Hinrichs et al., 1999; Orphan et al., 2001b; Zhang et al., 2003); many of these characteristics - especially the high abundance of sn-2-hydroxyarchaeol - are consistent with the close genetic relationship between ANME-2 and the Methanosarcinales. In contrast, low hydroxyarchaeol to archaeol ratios, the presence of both the $s n-2-$ and $s n-3$-hydroxyarchaeol isomers and/or relatively more abundant irregular isoprenoids are observed where the ANME-1 cluster is predominant (Michaelis et al., 2002; Aloisi et al., 2002). Although considerably more work is required to identify a chemotaxonomic signature for AOM archaeal communities, our data is consistent with ANME-2 and related groups being associated with the precipitation of the Gulf of Mexico carbonates. This is also consistent with work by Lanoil et al. (2001) who identified several archaeal gene sequences related to Methanosarcinales (73 of 93 archaeal clones), including two sequences (comprising 3 of 93 clones) related to ANME-2, and two gene sequences (comprising 16 of 93 clones) related to ANME-1 in Gulf of Mexico sediments associated with hydrates (although not collected from Green Canyon).

Non-isoprenoidal diethers were identified and characterized in Mediterranean mud volcano cold seep carbonate crusts (Pancost et al., 2001b; Aloisi et al., 2002) and Black Sea cold seep carbonate crusts (Stadnitskaia et al., 2003). Thiel et al. (2001) released $\mathrm{C}_{15}$ iso- and anteiso-branched hydrocarbons during ether cleavage of Black Sea carbonate crust extracts and inferred that these moieties derive from diethers of sulfate-reducing bacteria. Other work (Hinrichs et al., 2000; Werne et al., 2002; Zhang et al., 2003) has revealed that nonisoprenoidal diethers do occur in sediments but only in much lower concentrations than those reported by Aloisi et al. (2002). In the Gulf of Mexico, the abundances of non-isoprenoidal diethers are similar in the carbonates and non-lithified sediments, varying from 0.2 to $0.8 \mu \mathrm{g}$ g sediment ${ }^{-1}$ and 0.3 to $2.0 \mu \mathrm{g} \mathrm{g}$ crust $^{-1}$. Non-isoprenoidal diethers in Mediterranean mud volcano (Pancost et al., 2001b) and Black Sea (Stadnitskaia et al., 2003) carbonate crusts, as well as branched hydrocarbons released by ether cleavage from Black Sea crusts (Thiel et al., 2001), all have low $\delta^{13} \mathrm{C}$ values but are enriched in ${ }^{13} \mathrm{C}$ relative to co-occurring archaeal biomarkers. Again, our authigenic carbonate data display the same relationship.

Previous work has revealed the presence of ${ }^{13} \mathrm{C}$ depleted $\mathrm{C}_{31}$ and $\mathrm{C}_{32}$ hopanols and hopanoic acids in cold seep sediments and authigenic carbonates (Thiel et al., 1999, 2001; Pancost et al., 2000). Such compounds are common in marine and terrestrial sediments and could derive from a range of Bacteria, but the low $\delta^{13} \mathrm{C}$ values of cold seep 
hopanoids indicate that they derive from the methane-supported microbial community. In the Gulf of Mexico, hopanol and hopanoic acid abundances range from 0.6 to $15 \mu \mathrm{g} \mathrm{g}^{-1}$ in sediments (Zhang et al., 2003). Because hopanoids are thought to be restricted to aerobic bacteria (Rohmer et al., 1984), previous occurrences in cold seeps have been tentatively attributed to an $\mathrm{H}_{2} \mathrm{~S}$-oxidizing chemoautotroph, such as Beggiatoa (Pancost and Sinninghe Damsté, 2003) or some other aerobic bacterium. However, Thiel et al. (2003) identified ${ }^{13} \mathrm{C}$-depleted hopanoids in deep Black Sea cold seeps, clearly implicating an anaerobic organism as their source, and Sinninghe Damsté et al. (2004) have found hopanoids in strictly anaerobic ammonium-oxidizing bacteria (anammox). The Black Sea hopanoids, like those in our samples, occur as both the $17 \beta, 21 \beta(\mathrm{H})$ and $17 \alpha, 21 \beta(\mathrm{H})$ isomers, suggesting that a similar organism could serve as the source for Gulf of Mexico hopanoids.

Intact bacteriohopanoids have not previously been examined in modern cold seep sediments or carbonate rocks. The BHP aminotriol has been found in an ancient seep deposit (Burhan et al., 2002) but is relatively non-diagnostic, being produced by Type II methanotrophic bacteria (Neunlist and Rohmer, 1985a; Cvejic et al., 2000; Talbot et al., 2001), some cyanobacteria (Rohmer, 1993; Talbot et al., unpublished), nitrogen-fixing bacteria (Vilcheze et al., 1994; Bravo et al., 2001), purple non-sulphur bacteria (e.g., Neunlist et al., 1985; Flesch and Rohmer, 1989) and Nitrosomonas europaea (Seemann et al., 1999). The BHP aminotetrol has only been found in Type I and Type II (aerobic) methanotrophic bacteria (Neunlist and Rohmer, 1985a,b; Cvejic et al., 2000; Talbot et al., 2001). In the carbonate rock from site 185 , its presence could indicate Type II methanotrophs because in Type I methanotrophs it is always accompanied by 35-aminobacteriohopane-30,31,32,33,34pentol, which we do not observe. Aminotetrol is always accompanied by aminotriol (in varying relative abundance) in these organisms, suggesting that the aminotriol in our samples also derives from Type II methanotrophs. Evidence for the presence of aerobic bacteria has been found in fossil cold seep deposits (Peckmann et al., 1999; Thiel et al., 1999; Burhan et al., 2002; Peckmann and Thiel, 2004), and this work adds to the previously observed similarities between modern and ancient cold seep microbial communities as inferred by archaeal and bacterial biomarkers (e.g., Thiel et al., 1999).

Our biomarker abundance and isotopic data are consistent with previous analyses of cold seep carbonate rocks and sediments. Archaeal biomarkers, such as PMI, crocetane, archaeol, sn-2-hydroxyarchaeol and GDGTs, are all present in the Gulf of Mexico carbonates and have low $\delta^{13} \mathrm{C}$ values. Bacterial biomarkers, including non-isoprenoidal diethers and a range of hopanoids (including those with $17 \alpha, 21 \beta \mathrm{H})$ stereochemistry previously observed in Black Sea sediments), are also present in the carbonate rocks examined here but are enriched in ${ }^{13} \mathrm{C}$ relative to archaeal biomarkers. Thus, despite the presence of abundant biodegraded petroleum and the possibility that it is being oxidized by sulfate, the main participants of the AOM community archaea (possibly the ANME-2 group) and SRB (including perhaps novel species that synthesise non-isoprenoidal diethers) - are the same as those observed elsewhere. Moreover, the isotopic relationships between the cold seep archaea and bacteria have also been conserved, suggesting that the mechanism of AOM is the same at Gulf of Mexico cold seeps as at other cold seeps where petroleum is not present.

The abundance of bacterial and archaeal biomarkers in carbonates, and their potential to trace specific microbial communities, could be very useful in paleoecological investigations. Among the ancient cold seep sites that have been shown to contain microbial biomarkers are those associated with the Oligocene Lincoln Creek Formation (Thiel et al., 2001; Peckmann et al., 2002), the Miocene Marmorito Limestone (Thiel et al., 1999), the Eocene 'Whiskey Creek' deposit (Goedert et al., 2003) and the Jurassic Terres Noires Formation (Peckmann et al., 1999). However, current limits to our understanding of the chemotaxonomy of AOM communities usually prevents further insight than the identification of bacterial and/or archaeal communities. As this and other work in modern settings points out, there is considerable variability in the biomarker signatures; in relatively thermally immature settings, many of these biomarkers will be preserved and 
their identification could be useful in characterizing past AOM microbial consortia.

\subsection{Comparison of biomarkers in Gulf of Mexico sediments and authigenic carbonate rocks}

Previously Pancost and Sinninghe Damsté (2003) suggested that microbial communities associated with authigenic carbonate precipitation are different than those associated with AOM in sediments. This was largely because non-isoprenoidal diethers were initially found in Mediterranean mud volcano cold seep carbonate crusts but were absent in the nearby sediments. Other work has identified non-isoprenoidal diethers in other carbonate crusts (Stadnitskaia et al., 2003) but also in sediments (Hinrichs et al., 2000; Werne et al., 2002; Teske et al., 2002; Zhang et al., 2003) where they are present in lower concentrations than those reported by Aloisi et al. (2002).

In general, the Gulf of Mexico data suggests that AOM communities at a given site, while possibly rather heterogeneous (see Pancost et al., 2001a), are generally the same whether they are associated with carbonate precipitation or not. As described above, Zhang et al. (2003) noted that the distribution of archaeal lipids in Gulf of Mexico cold seep sediments is similar to that observed for the California Cascadia Ridge and Hydrate Ridge, but different from that observed for the Mediterranean mud volcano. In the Gulf of Mexico and the California margin, archaeol and sn-2-hydroxyarchaeol are most abundant and concentrations of PMI and crocetane are low (consistent with a predominance of ANME-2). In the Mediterranean, however, crocetane is as abundant as or even more abundant than archaeol in some sediments. In addition, in the Mediterranean samples, hydroxyarchaeol is always less abundant than archaeol, while the opposite is observed for the California Margin and Gulf of Mexico seeps (consistent with a predominance of ANME-2). Our authigenic carbonate data are broadly similar, indicating that variations associated with carbonate precipitation are less significant than large-scale geographic variability.

This also appears to be true for the sulfate-reducing bacterial community. Although non-isoprenoidal diether distributions do vary between authigenic carbon- ate rocks and sediments - in particular, the triplet of di- $\mathrm{C}_{15}$ glycerol diether isomers is not present in the sediments where only one isomer occurs - they are clearly present and abundant in both the rocks and sediments. Thus, we attribute the minor variations between rocks and sediments observed here and the more substantial variations observed between Mediterranean mud volcano crusts and sediments to the small-scale heterogeneity of seep environments rather than to a systematic difference between microbes associated with carbonate precipitation and those that are not.

\subsection{Implications for authigenic carbonate rock formation}

While carbonate precipitation is an important process in many modern and ancient settings (e.g., Ritger et al. 1987; Peckmann et al., 1999; Lein et al., 2002), it is a particularly significant component of carbon biogeochemistry in the Gulf of Mexico. Few other basins on the continental margins of the planet are characterized by such abundant authigenic carbonate rock, and nearly all carbonate in Gulf of Mexico sediments derives from authigenesis as sediment is washed into the rapidly subsiding basin from predominantly siliciclastic sources (e.g., Roberts et al., 1990; Roberts and Aharon, 1994). Moreover, carbonate precipitation has been a quantitatively significant biogeochemical process in the Gulf of Mexico since at least the Oligocene (Sassen et al., 1994a). In fact, so much carbonate rock has precipitated over geologic time that it affected the geology of the Gulf Coast during the Cenozoic and it serves as the host rock for economic accumulations of, for example, sulfur.

Scientists have been studying hydrocarbon-related carbonate in the Gulf of Mexico area for years, with Feely and Kulp (1957) the first to link authigenic carbonate rocks to microbial activity. These authors were the first to explain that the billions of tons of carbonate rock over Gulf Coast salt domes were strongly depleted in ${ }^{13} \mathrm{C}$ because they formed from microbial oxidation of both crude oil and gas at low temperatures; by extension, the sulfur present in such rocks almost certainly derived from bacterial sulfate reduction (Sassen et al., 1994a,b). While a direct comparison cannot be drawn between the cold seep 
carbonates of our study and those associated with salt domes, it seems that both types of carbonate deposit derive from the anaerobic oxidation of reduced carbon compounds.

Our biomarker data, consistent with that from other settings, indicate that carbonate precipitation at cold seeps is associated with the same AOM-mediating community as is present in associated sediments. However, biomarkers are typically present in high abundances in carbonates, despite the fact that carbonate precipitation will dilute biomarker abundances on a per gram of rock basis. This suggests that carbonate precipitation preferentially occurs where AOM communities are the largest and, by extension, methane flux is the greatest. This is consistent with arguments by Aloisi et al. (2002) and many others that $\mathrm{AOM}$ is particularly favorable for carbonate precipitation because it significantly increases pore-water bicarbonate concentrations; in contrast, aerobic methanotrophy produces $\mathrm{CO}_{2}$, which will cause calcium carbonate dissolution (Paull et al., 1992). In fact, $\mathrm{AOM}$ in the Gulf of Mexico has resulted in the formation of these carbonate rocks despite: 1) high concentrations of biodegraded petroleum, which is being at least partly remineralised resulting in $\mathrm{CO}_{2}$ production; and 2) evidence for aerobic methanotrophy, and thus $\mathrm{CO}_{2}$ production, in the carbonate rock from site 185 .

These conclusions have important implications for the role of methane and specifically gas hydrates as agents of climate change. AOM cannot only rapidly convert methane to oxidized carbon species in marine sediments, but subsequent carbonate precipitation will sequester this carbonate in chemically stable carbonate rock. In fact, this AOM, along with petroleum oxidation, must serve as an important modulator of carbon biogeochemistry in the Gulf of Mexico today as reflected by the vast quantity of ${ }^{13} \mathrm{C}$-depleted authigenic carbonate rock found in the Green Canyon area. For example, a nearby area (GC140) contains a circular area of outcropping authigenic carbonate rock that is roughly $1 \mathrm{~km}$ across and has relief $>10 \mathrm{~m}$ (Roberts et al., 1990). Thus, for gas hydrate destabilisation to affect climate change as postulated by previous workers (e.g., Dickens, 2001, who assumes a quantitative flux of methane from hydrates to the ocean-atmosphere reservoir), it must be released very rapidly relative to the rate of adaptation of the anaerobic methane-oxidizing community. It is possible that identification of biomarkers in ancient carbonates and their chemotaxonomic application, as discussed above, could be a powerful tool in studying these processes in ancient sediments.

\section{Conclusions}

${ }^{13} \mathrm{C}$-depleted archaeal and bacterial biomarkers are abundant in Gulf of Mexico authigenic carbonate rocks, revealing that AOM-mediating organisms are closely associated with carbonate authigenesis. Moreover, the rocks contain the same biomarkers as found in nearby non-lithified sediments, suggesting that the organisms associated with carbonate precipitation are the same as those that live elsewhere in the hydrocarbon seep environment. Notable characteristics of the biomarker assemblages include the presence of: diverse archaeal biomarkers, including diethers, tetraethers and irregular isoprenoid hydrocarbons; bacterial biomarkers, including three di- $\mathrm{C}_{15}$ glycerol diether isomers; and aerobic(?) bacterial biomarkers, including diverse hopanoids such as $17 \alpha, 21 \beta(\mathrm{H})$-bishomohopanoic acid, bacteriohopanpolyols, and a tentatively identified trinorhopanoid ketone. The organisms reflected in these biomarker assemblages play a critical role in Gulf of Mexico carbon biogeochemistry; by oxidizing methane to bicarbonate, they insure that significant amounts of hydrocarbon-derived carbon is ultimately sequestered as relatively stable authigenic carbonate rock.

\section{Acknowledgements}

Support for this research was provided by the Petroleum Research Fund (CLZ), The National Undersea Research Program (CLZ and RS), the National Science Foundation Biocomplexity Program (CLZ and RS), and the Royal Society of the United Kingdom (RDP). We also thank Ian Bull of the OGU (University of Bristol) for analytical support and Marcus Elvert and Volker Thiel for very useful comments on an earlier version of this manuscript. 


\section{Appendix A}

Diethers

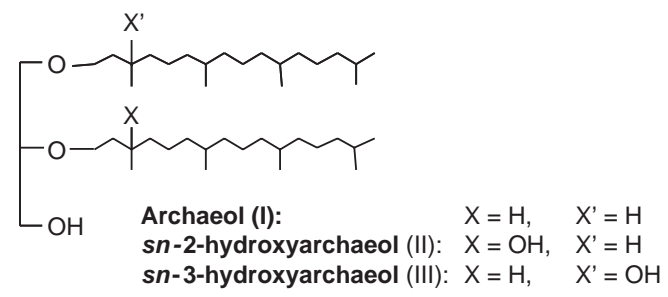

$\mathrm{PMI}(\mathrm{V})$

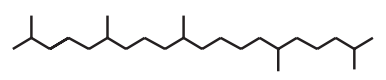

Crocetane (IV)<smiles>CC(C)CCCC(C)CCCCC(C)CCCC(C)C</smiles>

Biphytanes (comprising GDGTs; VI)

A

B

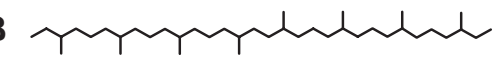

$c$ renthen

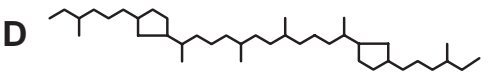

Non-isoprenoidal glycerol diethers

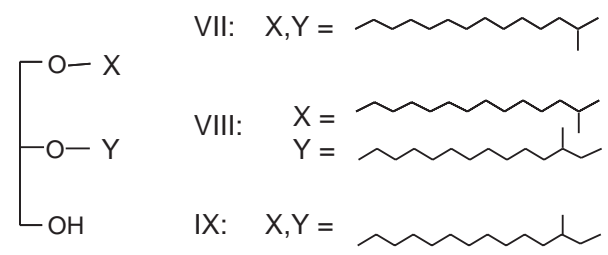

\section{References}

Aharon, P., Fu, B., 2000. Microbial sulfate reduction rates and sulfur and oxygen isotope fractionations at oil and gas seeps in deepwater Gulf of Mexico. Geochimica et Cosmochimica Acta 64, 233-246.

Aloisi, G., Bouloubassi, I., Heijs, S.K., Pancost, R.D., Pierre, C., Sinninghe Damste, J.S., Gottschal, J.C., Forney, L.J., Rouchy, J.M., 2002. $\mathrm{CH}_{4}$-consuming microorganisms and the formation of carbonate crusts at cold seeps. Earth and Planetary Science Letters 203, 195-203.

Bian, L.Q., Hinrichs, K.-U., Xie, T.M., Brassell, S.C., Iversen, H., Fossing, H., Jørgensen, B.B., Hayes, J.M., 2001. Algal and archaeal polyisoprenoids in a recent marine sediment: molecular isotopic evidence for anaerobic oxidation of methane. Geochemistry Geophysics Geosystems 2 (art. no.-2000GC000112).

Boetius, A., Ravenschlag, K., Schubert, C.J., Rickert, D., Widdel, F., Gieseke, A., Amann, R., Jørgensen, B.B., Witte, U., Pfannkuche, O., 2000. A marine microbial consortium appar- ently mediating anaerobic oxidation of methane. Nature 407 , $623-626$

Boone, D.R., Whitman, W.B., Rouviere, P., 1993. Microbiology: diversity and taxonomy of methanogens. In: Ferry, J.G. (Ed.), Methanogenesis: Ecology, Physiology, Biochemistry, and Genetics. Chapman and Hall, New York, pp. 35-80.

Bravo, J.-M., Perzel, M., Härtner, T., Kannenberg, E.L., Rohmer, M., 2001. Novel methylated triterpenoids of the gammacerane series from the nitrogen-fixing bacterium Bradyrhizobium japonicum USDA 110. European Journal of Biochemistry 268, $1323-1331$.

Brooks, J.M., Cox, H.B., Bryant, W.R., Kennicutt, M.C. II, Mann, R.G., McDonald, T.J., 1986. Association of gas hydrates and oil seepage in the Gulf of Mexico. Organic Geochemistry 10, $221-234$.

Burhan, R.Y.P., Trendel, J.M., Adam, P., Wehrung, P., Albrecht, P., Nissenbaum, A., 2002. Fossil bacterial ecosystem at methane seeps: origin of organic matter from Be'eri sulfur deposit, Israel. Geochimica et Cosmochimica Acta 66, 4085-4101. 
Costantino, V., Fattorusso, E., Imperatore, C., Mangoni, A., 2001. A biosynthetically significant new bacteriohopanoid present in large amounts in the Caribbean sponge Plakortis simplex. Tetrahedron $57,4045-4048$.

Cvejic, J.H., Bodrossy, L., Kovács, K.L., Rohmer, M., 2000. Bacterial triterpenoids of the hopane series from the methanotrophic bacteria Methylocaldum spp.: phylogenetic implications and first evidence for an unsaturated aminobacteriohopanepolyol. FEMS Microbiology Letters 182, 361-365.

De Rosa, M., Gambacorta, A., 1988. The lipids of archaebacteria. Progress in Lipid Research 27, 153-175.

Dickens, G.R., 2001. Modeling the global carbon cycling with a gas hydrate capacitor: significance for the latest Paleocene thermal maximum. In: Paull , C.K., Dillon, W.P. (Eds.), Natural Gas Hydrates: Occurrence, Distribution, and Detection. American Geophysical Union, Washington, D.C., pp. 19-38.

Dickens, G.R., O’Neil, J.R., Rea, D.K., Owen, R.M., 1995. Dissociation of oceanic methane hydrate as a cause of the carbon isotope excursion at the end of the Paleocene. Paleoceanography 10, $965-971$.

Elvert, M., Suess, E., Whiticar, M.J., 1999. Anaerobic methane oxidation associated with marine gas hydrates: superlight Cisotopes from saturated and unsaturated $\mathrm{C}_{20}$ and $\mathrm{C}_{25}$ irregular isoprenoids. Naturwissenschaften 86, 295-300.

Elvert, M., Suess, E., Greinert, J., Whiticar, M.J., 2000. Archaea mediating anaerobic methane oxidation in deep-sea sediments at cold seeps of the eastern Aleutian subduction zone. Organic Geochemistry 31, 1175-1187.

Elvert, M., Greinert, J., Suess, E., Whiticar, M.J., 2001. Carbon isotopes of biomarkers derived from methane-oxidizing microbes at Hydrate Ridge, Cascadia Convergent Margin. In: Paull, C.K., Dillon, W.P. (Eds.), Natural Gas Hydrates: Occurrence, Distribution, and Detection. American Geophysical Union, Washington, D.C., pp. 115-129.

Elvert, M., Boetius, A., Knittel, K., Jorgensen, B.B., 2003. Characterization of specific membrane fatty acids as chemotaxonomic markers for sulfate-reducing bacteria involved in anaerobic oxidation of methane. Geomicrobiology Journal 20, 403-419.

Farrimond, P., Head, I.M., Innes, H.E., 2000. Environmental influence on the biohopanoid composition of recent sediments. Geochimica et Cosmochimica Acta 64, 2985-2992.

Feely, H.W., Kulp, J.L., 1957. Origin of Gulf Coast salt-dome sulfur deposits. Bulletin of the American Association of Petroleum Geologists 41, $1802-1853$.

Flesch, G., Rohmer, M., 1989. Prokaryotic hopanoids: the biosynthesis of the bacteriohopane skeleton. Formation of isoprenic units from two distinct acetate pools and a novel type of carbon/ carbon linkage between a triterpene and D-ribose. European Journal of Biochemistry 175, 405-411.

Goedert, J.L., Thiel, V., Schmale, O., Rau, W.W., Michaelis, W., Peckmann, J., 2003. The Late Eocene 'Whiskey Creek' methane-seep deposit (Western Washington State): Part I. Geology, palaeontology, and molecular geobiology. Facies 48, 223-239.

Greinert, J., Bollwerk, S.M., Derkachev, A., Bohrmann, G., Suess, E., 2002. Massive barite deposits and carbonate mineralization in the Derugin Basin, Sea of Okhotsk: precipitation processes at cold seep sites. Earth and Planetary Science Letters 203, $165-180$.

Henriet, J.P., Mienert, J., 1998. Gas Hydrates: Relevance to World Margin Stability and Climate Change. Special Publications, vol. 137. Geological Society, London. 338 pp.

Hinrichs, K.-U., Hayes, J.M., Sylva, S.P., Brewer, P.G., DeLong, E.F., 1999. Methane-consuming archaebacteria in marine sediments. Nature 398, 802-805.

Hinrichs, K.-U., Sylva, S.P., Hayes, J.M., Summons, R.E., Orphan, V., 2000. Molecular and isotopic analysis of anaerobic methaneoxidizing communities in marine sediments. Organic Geochemistry $31,1685-1701$.

Innes, H.E., Bishop, A.N., Head, I.M., Farrimond, P., 1997. Preservation and diagenesis of hopanoids in Recent lacustrine sediments of Priest Pot, England. Organic Geochemistry 26, $565-576$.

Kastner, M., 2001. Gas hydrates in convergent margins: formation, occurrence, geochemistry and global significance. In: Paull, C.K., Dillon, W.P. (Eds.), Natural Gas Hydrates: Occurrence, Distribution, and Detection. American Geophysical Union, Washington, D.C., pp. 67-86.

Kennett, J.P., Cannariato, K.G., Hendy, I.L., Behl, R.J., 2000. Carbon isotopic evidence for methane hydrate instability during Quaternary interstadials. Science 288, 128-133.

Kim, H.-Y., Norman Jr., S., 1990. Separation of lipid classes by solid phase extraction. Journal of Lipid Research 31, 2285-2289.

Koga, Y., Morii, H., Akagawa-Matsushita, M., Ohga, M., 1998. Correlation of polar lipid composition with 16S rRNA phylogeny in methanogens. Further analysis of lipid component parts. Bioscience, Biotechnology and Biochemistry 62, 230-236.

Kvenvolden, K.A., Lorenson, T.D., 2001. The global occurrence of natural gas hydrates. In: Paull, C.K., Dillon, W.P. (Eds.), Natural Gas Hydrates: Occurrence, Distribution, and Detection. American Geophysical Union, Washington, D.C., pp. 3-18.

Lanoil, B.D., Sassen, R., La Duc, M.T., Sweet, S.T., Nealson, K.H., 2001. Bacteria and Archaea physically associated with Gulf of Mexico gas hydrates. Applied and Environmental Microbiology $67,5143-5153$.

Lein, A.Y., Ivanov, M.V., Pimenov, N.V., Gulin, M.B., 2002. Geochemical peculiarities of the carbonate constructions formed during microbial oxidation of methane under anaerobic conditions. Microbiology 71, 78-90.

MacDonald, I.R., Boland, G.S., Baker, J.S., Brooks, J.M., Kennicutt II, M.C., Bidigare, R.R., 1989. Gulf of Mexico hydrocarbon seep communities: II. Spatial distribution of seep organisms and hydrocarbons at Bush Hill. Marine Biology 101, 235-247.

Michaelis, W., Seifert, R., Nauhaus, K., Treude, T., Thiel, V., Blumenberg, M., Knittel, K., Gieseke, A., Peterknecht, K., Pape, T., Boetius, A., Amann, R., Jørgensen, B.B., Widdel, F., Peckmann, J., Pimenov, N.V., Gulin, M.B., 2002. Microbial reefs in the Black Sea fueled by anaerobic oxidation of methane. Science 297, 1013-1015.

Milkov, A.V., Sassen, R., 2001. Estimate of gas hydrate resource, northwestern Gulf of Mexico continental slope. Marine Geology 179, $71-83$.

Milkov, A.V., Claypool, G.E., Lee, Y.J., Xu, W.Y., Dickens, G.R., Borowski, W.S., 2003. In situ methane concentrations, at 
Hydrate Ridge, offshore Oregon: new constraints on the global gas hydrate inventory from an active margin. Geology 31 , $833-836$.

Mills, H.J., Hodges, C., Wilson, K., MacDonald, I.R., Sobecky, P.A., 2003. Microbial diversity in sediments associated with surface-breaching gas hydrate mounds in the Gulf of Mexico. FEMS Microbiology, Ecology 46, 39-52.

Nelson, D.C., Fisher, C.R., 1995. Chemoautotrophic and methanotrophic endosymbiotic bacteria at deep-sea vents and seeps. In: Karl, D.M. (Ed.), The Microbiology of Deep-sea Hydrothermal Vents. CRC Press, New York, pp. 125-167.

Neunlist, S., Rohmer, M., 1985a. Novel hopanoids from the methylotrophic bacteria Methylococcus capsulatus and Methylomonas methanica (22S)-35-aminobacteriohopane-30,31,32,33,34-pentol and (22S)-35-amino-3b-methylbacteriohopane-30,31,32,33, 34-pentol. Biochemical Journal 231, 635-639.

Neunlist, S., Rohmer, M., 1985b. The hopanoids of 'Methylosinus trichosporium': aminobacteriohopanetriol and aminobacteriohopanetetrol. Journal of General Microbiology 131, 1363-1367.

Neunlist, S., Holst, O., Rohmer, M., 1985. Prokaryotic triterpenoids: the hopanoids of the purple non-sulphur bacterium Rhodomicrobium vannielii: an aminotriol and its aminoacyl derivatives, $N$-tryptophanyl and $N$-ornithinyl aminotriol. European Journal of Biochemistry 147, 561-568.

Orphan, V.J., House, C.H., Hinrichs, K.-U., McKeegan, K.D., DeLong, E.F., 2001a. Methane-consuming archaea revealed by directly coupled isotopic and phylogenetic analysis. Science 293, 484-487.

Orphan, V.J., Hinrichs, K.-U., Ussler III, W., Paull, C.K., Taylor, L.T., Sylva, S.P., Hayes, J.M., Delong, E.F., 2001b. Comparative analysis of methane-oxidizing archaea and sulfate-reducing bacteria in anoxic marine sediments. Applied and Environmental Microbiology 67, 1922-1934.

Pancost, R.D., Sinninghe Damsté, J.S., 2003. Carbon isotopic compositions of prokaryotic lipids as tracers of carbon cycling in diverse settings. Chemical Geology 195, 29-58.

Pancost, R.D., Sinninghe Damsté, J.S., De Lint, S., van der Maarel, M.J.E.C., Gottschal, J.C.the MEDINAUT Shipboard Scientific Party, 2000. Biomarker evidence for widespread anaerobic methane oxidation in Mediterranean sediments by a consortium of methanogenic archaea and bacteria. Applied and Environmental Microbiology 66, 1126-1132.

Pancost, R.D., Hopmans, E.C., Sinninghe Damsté, J.S., the MEDINAUT Shipboard Scientific Party, 2001a. Archaeal lipids in Mediterranean cold seeps: molecular proxies for anaerobic methane oxidation. Geochimica et Cosmochimica Acta 65, $1611-1627$.

Pancost, R.D., Bouloubassi, I., Aloisi, G., Sinninghe Damsté, J.S., 2001b. Three series of non-isoprenoidal dialkyl glycerol diethers in cold-seep carbonate crusts. Organic Geochemistry 32, 695-707.

Paull, C.K., Chanton, J.P., Neumann, A.C., Coston, J.A., Martens, C.S., Showers, W., 1992. Indicators of methane-derived carbonates and chemosynthetic organic carbon deposits: examples from the Florida Escarpment. Palaios 7, 361-375.

Peckmann, J., Thiel, V., 2004. Carbon cycling at ancient methaneseeps. Chemical Geology 205, 443-467.
Peckmann, J., Thiel, V., Michaelis, W., Clari, P., Gaillard, C., Martire, L., Reitner, J., 1999. Cold seep deposits of Beauvoisin (Oxfordian; southeastern France) and Marmorito (Miocene; northern Italy): microbially induced authigenic carbonates. International Journal of Earth Sciences 88, 60-75.

Peckmann, J., Goedert, J.L., Thiel, V., Michaelis, W., Reitner, J., 2002. A comprehensive approach to the study of methane-seep deposits from the Lincoln Creek Formation, western Washington State, USA. Sedimentology 49, 855-873.

Peters, K.E., Moldowan, J.M., 1991. Effects of source, thermal maturity, and biodegradation on the distribution and isomerization of homohopanes in petroleum. Organic Geochemistry 17, 47-61.

Reeburgh, W.S., 1996. "Soft spots" in the global methane budget. In: Lidstrom, M.E., Tabita, F.R. (Eds.), Microbial Growth on $\mathrm{C}_{1}$ Compounds. Kluwer Academic Publishers, Dordrecht, pp. 334-342.

Ritger, S., Carson, B., Suess, E., 1987. Methane-derived authigenic carbonates formed by subduction induced pore-water expulsion along the Oregon Washington Margin. Geological Society of America Bulletin 98, 147-156.

Roberts, H.H., Aharon, P., 1994. Hydrocarbon-derived carbonate buildups of the northern Gulf of Mexico continental slope: a review of submersible investigations. Geo-Marine Letters 14, $135-148$.

Roberts, H.H., Carney, R., 1997. Evidence of episodic fluid, gas, and sediment venting on the northern Gulf of Mexico slope. Economic Geology 92, 863-879.

Roberts, H.H., Aharon, P., Carney, R., Larkin, J., Sassen, R., 1990. Seafloor responses to hydrocarbon seeps, Louisiana continental slope. Geo-Marine Letters 10, 232-243.

Rohmer, M., 1993. The biosynthesis of the triterpenoids of the hopane series in the eubacteria: a mine of new enzyme reactions. Pure and Applied Chemistry 65, 1293-1298.

Rohmer, M., Bouvier-Nave, P., Ourisson, G., 1984. Distribution of hopanoid triterpenes in prokaryotes. Journal of General Microbiology 130, 1137-1150.

Sassen, R., Roberts, H.H., Aharon, P., Larkin, J., Chinn, E.W., Carney, R., 1993. Chemosynthetic bacterial mats at cold hydrocarbon seeps, Gulf of Mexico continental slope. Organic Geochemistry 20, 77-89.

Sassen, R., MacDonald, I.R., Requejo, A.G., Guinasso, J.N.L., Kennicutt, M.C., Sweet, S.T., Brooks, J.M., 1994a. Organic geochemistry of sediments from chemosynthetic communities, Gulf of Mexico slope. Geo-Marine Letters 14, 110-119.

Sassen, R., Cole, G.A., Drozd, R.A., Roberts, H.H., 1994b. Oligocene to Holocene hydrocarbon migration and salt dome carbonates, northern Gulf of Mexico. Marine and Petroleum Geology $11,55-65$.

Sassen, R., MacDonald, I.R., Guinasso, J.N.L., Joye, S., Requejo, A.G., Sweet, S.T., Alcala-Herrera, J., DeFreitas, D.A., Schink, D.R., 1998. Bacterial methane oxidation in sea-floor gas hydrate: significance to life in extreme environments. Geology 26, $851-854$.

Sassen, R., Roberts, H.H., Milkov, A.V., DeFreitas, D.A., 2001. Sea floor vents, seeps, gas hydrate: relation to flux rate from the deep Gulf of Mexico petroleum system: 2001 GCSSEPM Re- 
search Foundation. 21st Ann. Res. Conf., Petroleum Systems of Deep-Water Basins. , pp. 489-505.

Schouten, S., van der Maarel, M.J.E.C., Huber, R., Sinninghe Damsté, J.S., 1997. 2,6,10,15,19-Pentamethylicosenes in Methanolobus bombayensis, a marine methanogenic archaeon, and in Methanosarcina mazei. Organic Geochemistry 26, 409-414.

Schouten, S., Hopmans, E.C., Pancost, R.D., Sinninghe Damsté, J.S., 2000. Widespread occurrence of structurally diverse tetraether membrane lipids: evidence for the ubiquitous presence of low-temperature relatives of hyperthermophiles. Proceedings of the National Academy of Science of the United States of America 97, 14421-14426.

Seemann, M., Bisseret, P., Tritz, J.-P., Hooper, A.B., Rohmer, M., 1999. Novel bacterial triterpenoids of the hopane series from Nitrosomonas europea and their significance for the formation of the $\mathrm{C}_{35}$ bacteriohopane skeleton. Tetrahedron Letters 40, $1681-1684$.

Sinninghe Damsté, J.S., Schouten, S., Hopmans, E.C., van Duin, A.C.T., Geenevasen, J.A.J., 2002. Crenarchaeol: the characteristic core glycerol dibiphytanyl glycerol tetraether membrane lipid of cosmopolitan pelagic crenarchaeota. Journal of Lipid Research 43, 1641-1651.

Sinninghe Damsté, J.S., Rijpstra, W.I.C., Schouten, S., Fuerst, J.A., Jetten, M.S.M., Strous, M., 2004. The occurrence of hopanoids in planctomycetes: implications for the sedimentary biomarker record. Organic Geochemistry 35, 561-566.

Sprott, G.D., Ekiel, I., Patel, G.B., 1993. Metabolic pathways in Methanococcus jannaschii and other methanogenic bacteria. Applied and Environmental Microbiology 59, 1092-1098.

Stadnitskaia, A., Baas, M., Ivanov, M.K., van Weering, T.C.E., Sinninghe Damsté, J.S., 2003. Novel archaeal macrocyclic diether core membrane lipids in a methane-derived carbonate crust from a mud volcano in the Sorokin Trough, NE Black Sea. Archaea 1, 165-173.

Talbot, H.M., Watson, D.F., Murrell, J.C., Carter, J.F., Farrimond, P., 2001. Analysis of intact bacteriohopanepolyols from methylotrophic bacteria by reversed-phase high-performance liquid chromatography-atmospheric pressure chemical ionisation mass spectrometry. Journal of Chromatography, A 921, 175-185.

Talbot, H.M., Squier, A.H., Keely, B.J., Farrimond, P., 2003a. Atmospheric pressure chemical ionisation reversed-phase liquid chromatography/ion trap mass spectrometry of intact bacteriohopanepolyols. Rapid Communications in Mass Spectrometry $17,728-737$.
Talbot, H.M., Summons, R., Jahnke, L., Farrimond, P., 2003b. Characteristic fragmentation of bacteriohopanepolyols during atmospheric pressure chemical ionisation liquid chromatography/ion trap mass spectrometry. Rapid Communications in Mass Spectrometry $17,2788-2796$.

Teske, A., Hinrichs, K.-U., Edgcomb, V., Gomez, A.D., Kysela, D., Sylva, S.P., Sogin, M.L., Jannasch, H.W., 2002. Microbial diversity of hydrothermal sediments in the Guaymas Basin: evidence for anaerobic methanotrophic communities. Applied and Environmental Microbiology 68, 1994-2007.

Thiel, V., Peckmann, J., Seifert, R., Wehrung, P., Reitner, J., Michaelis, W., 1999. Highly isotopically depleted isoprenoids: molecular markers for ancient methane venting. Geochimica et Cosmochimica Acta 63, 3959-3966.

Thiel, V., Peckmann, J., Richnow, H.H., Luth, U., Reitner, J., Michaelis, W., 2001. Molecular signals for anaerobic methane oxidation in Black Sea seep carbonates and a microbial mat. Marine Chemistry 73, 97-112.

Thiel, V., Blumenberg, M., Pape, T., Seifert, R., Michaelis, W., 2003. Unexpected occurrence of hopanoids at gas seeps in the Black Sea. Organic Geochemistry 34, 81-87.

Tornabene, T.G., Langworthy, T.A., 1979. Diphytanyl and dibiphytanyl glycerol ether lipids of methanogenic archaebacteria. Science 203, 51-53.

Vilcheze, C., Llopiz, P., Neunlist, S., Poralla, K., Rohmer, M., 1994. Prokaryotic triterpenoids: new hopanoids from the nitrogenfixing bacteria Azotobacter vinelandii, Beijerinckia indica and Beijerinckia mobilis. Microbiology 140, 2749-2753.

Wakeham, S.G., Lewis, C.M., Hopmans, E.C., Schouten, S., Sinninghe Damsté, J.S., 2003. Archaea mediate anaerobic oxidation of methane in deep euxinic waters of the Black Sea. Geochimica et Cosmochimica Acta 67, 1359-1374.

Werne, J.P., Baas, M., Sinninghe Damsté, J.S., 2002. Molecular isotopic tracing of carbon flow and trophic relationships in a methane-supported benthic microbial community. Limnology and Oceanography 47, 1694-1701.

Zhang, C.L., Li, Y., Wall, J.D., Larsen, L., Sassen, R., Huang, Y., Wang, Y., Peacock, A., White, D.C., Horita, J., Cole, D.R., 2002. Lipid and carbon isotopic evidence of methane-oxidizing and sulfate-reducing bacteria in association with gas hydrates from the Gulf of Mexico. Geology 30, 239-242.

Zhang, C.L., Pancost, R.D., Sassen, R., Qian, Y., Macko, S.A., 2003. Archaeal lipid biomarkers and isotopic evidence of anaerobic methane oxidation associated with gas hydrates in the Gulf of Mexico. Organic Geochemistry 34, 827-836. 